\title{
Conceptual Metaphors of Time in the Sonnets of Shakespeare: A Cognitive Linguistic Approach
}

\author{
Mufeed Al-Abdullah ${ }^{1}$ \\ ${ }^{1}$ Department of English, College of Arts, Jerash University, Jerash, Jordan \\ Correspondence: Mufeed Al-Abdullah, Department of English, College of Arts, Jerash University, Jerash, Jordan. \\ E-mail: mufeedh2014@gmail.com
}

Received: March 2, 2020 Accepted: April 3, 2020 Online Published: April 6, 2020

doi:10.5539/ells.v10n2p1 URL: https://doi.org/10.5539/ells.v10n2p1

\begin{abstract}
The article studies the conceptual metaphors of time in the sonnets of Shakespeare in light of the Conceptual Metaphor Theory (CMT) of Lakoff and Johnson (1980) presented in their book, Metaphors We Live By, and Kovecses' (2002) informative views in his book, Metaphor: A Practical Introduction. The extracted metaphors selected from a variety of sonnets that tackle the theme of time will be divided into three sub-categories: structural, ontological, and orientational. Under ontological metaphors, the study addresses metaphors in the forms of personification, metonymy, and synecdoche. Using the cognitive approach to understand the abstract concept of time in terms of a variety of concrete concepts with experiential dimension enables the reader to perceive this concept from different perspectives. The study hopes to show that the cluster of source domains Shakespeare provides in the metaphors maps an association of multidimensional possibilities that improve our understanding of time. Also, this consortium of possibilities points to the creativity and the wide scope of Shakespeare's vision. The study hopes to add another vantage point from which to view Shakespeare's presentation of time in light of modern progress in the studies of conceptual metaphors and cognitive poetics.
\end{abstract}

Keywords: cognitive poetics, conceptual metaphors, Shakespeare, sonnets, conventional metaphors

\section{Introduction}

Time is an elusive abstract concept to understand. St. Augustine explains the elusiveness of the concept, saying: "What then is time? If no one asks me, I know: if I wish to explain it to one that asketh, I know not" (Confessions; Book 11, chap. 14). The subject of time is a pervasive theme in the sonnets of Shakespeare. Indeed, the word "time" recurs seventy-nine times (Moreira, 2017, p. 250) and is available in the poems in the objective and subjective forms. Objective or clock time is the type that passes regardless of human psychology and consciousness, whereas subjective time is related to the domain of neuropsychology and memory. In his sonnets, Shakespeare retains this dual nature of time (Al-Abdullah, 2020, p. 67). Objective time is presented as divisible and countable. This notion which permeates the sonnets captures the Aristotelian perception of time. For Aristotle time is divisible and countable because it is an incessant succession like motion. This way, time is known by the change it affects and the absence of change means the nonexistence of time. Aristotle states:

Just as motion is a perpetual succession, so also is time. But every simultaneous time is self-identical; for the 'now' as a subject is an identity, but it accepts different attributes. The 'now' measures time, in so far as time involves the 'before and after' (Physics, IV, 11, p. 23).

Shakespeare's sonnets express a pessimistic vision of the procession of time which correlates our life with mutability and change (Al-abdullah, 2020). The Elizabethan poet retains and gives prominence to this Aristotelian view in his sonnets that address the issue of time. For instance, sonnet 12 observes this Aristotelian concept that time can be divided and measured:

When I do count the clock that tells the time,

And see the brave day sunk in hideous night;

When I behold the violet past prime,

And sable curls all silvered o'er with white:

When lofty trees I see barren of leaves, 
Which erst from heat did canopy the herd,

And summer's green all girded up in sheaves

Borne on the bier with white and bristly beard ... (1-8)

In these lines, Shakespeare gives examples from nature that show the procession of change objective time inflicts on the life cycle of a number of plants and natural phenomena. In the third quatrain, Shakespeare addresses both objective and subjective time. The poet asserts that human life suffers the mutations of time like other beings. Individuals will eventually be reaped by time's scythe. The beautiful young friend of the poet will be no exception to this reality:

Then of thy beauty do I question make,

That thou among the wastes of time must go,

Since sweets and beauties do themselves forsake,

And die as fast as they see others grow... (9-12)

The young friend is invited to a mental time journey to imagine what will happen to him. Mental time travel is a manifestation of subjective time that is heavily used in the sonnets of Shakespeare (Al-Abdullah, 2020).

The sonnets of Shakespeare also reflect some of St. Augustine's views on the passage of time, which divide time into the three components of past, present, and future. According to St. Augustine, time is a stream in which future moments turn to present and then to past. This mundane time is different from the eternal time which remains permanently present. He contemplates on the issue, saying:

What then is time? If no one asks me, I know: if I wish to explain it to one that asketh, I know not: yet I say boldly that I know, that if nothing passed away, time past were not; and if nothing were coming, a time to come were not; and if nothing were, time present were not. Those two times then, past and to come, how are they, seeing the past now is not, and that to come is not yet? But the present, should it always be present, and never pass into time past, verily it should not be time, but eternity (Confessions; Book 11, chap. 14).

St. Augustine realizes the difficulty of defining the concept of time. He, however, distinguishes between eternal and temporary concepts of time. Temporary time is manifested by movement and change when present moments recline to the past and moments to come replace them and become present. Past moments do not exist anymore and future moments are not yet and, thus, do not exist either. He explains that if present moments do not pass to past moments, then there will be no time. Rather, there will be eternity.

This study finds in cognitive metaphorical mediation an appropriate means for understanding the evasive concept of time. Generally, metaphors provide a convenient means of expressing the human experience of time when the language register fails to provide an accurate description of that abstract experience. The conventional concept of metaphors falls short of furnishing an adequate medium for explaining the concept of time in Shakespeare's sonnets because this type of metaphor is language-bound and is meant to improve the rhetorical input of communication (Kovecses, 2002). This study adopts modern CMT as an adequate medium for the explanation of the human experience of time. This theory can be very helpful in uncovering the mysteries of the pervasive concept in the sonnets of Shakespeare. This type of metaphor belongs to the domain of cognitive linguistics in which one concept is understood in terms of another.

\section{Theoretical Framework}

This article draws on George Lakoff and Mark Johnson's (1980) CMT presented in Metaphors We Live By and on Zoltan Kovecses' (2002) elaboration on that theory in Metaphor: A practical introduction. Lakoff and Johnson's new theory contested the deeply rooted pervasive views of Aristotle on metaphor that dominated Western thought for over two millennia (Wood, 2015, p. 362).

The essence of Lakoff and Johnson's theory and Kovecses' notions of conceptual metaphors developed because of the difficulty and inexpressibility of abstract or metaphysical concepts. They find that metaphoric mediation becomes a means for understanding these concepts. Lakoff and Johnson (1980) explain that the function of these metaphors is "to conceptualize the metaphysical in terms of the physical, that is, we conceptualize the less clearly delineated in terms of the more clearly delineated" (p. 59). This study examines a selection of conceptual metaphors of time from the collection of Shakespeare's sonnets under the categories of structural, ontological, orientational metaphors drawn from Lakoff and Johnson (1980). The study also examines metaphors based on personification, metonymy, and synecdoche which are included as sub-categories of metaphor in CMT. This theory states that metaphors are integral to human everyday language of communication. Concerning metaphors 
in poetry, Lakoff and Turner hold that "the metaphoric innovations of poets are shown thereby to consist not in the new creation of metaphoric thought but in the marshalling of already existing forms of metaphoric thought to form new extensions and combinations of old metaphorical mappings" (Lakoff \& Turner,1989, p. 268) This study, however, departs from Lakoff and Johnson's views in the sense that Shakespeare's metaphors do not always belong to everyday language of communication, but rather innovated by Shakespeare and some of them find their way to normal language. Besides, the numerous metaphors created by the Elizabethan poet exceed the possibilities of the linguistic register of the common man and tackle the inexpressible abstraction of the concept of time in the realm of philosophical theories on the subject. The researcher finds in the conceptual theory of Lakoff and Johnson (1980) a means to trigger further analysis of Shakespeare's conceptual metaphors on time in the sonnets in the hope to shed light on the concepts of both time and metaphor.

\section{Review of Literature}

In a conference in Chicago in 1978, Wayne C. Booth described the situation of scholarship on the concept of metaphor as thus:

Explicit discussions of something called metaphor have multiplied astronomically in the last fifty years.... Students of metaphor have positively pullulated. ... We shall soon no doubt have more metaphoricians than metaphysicians ... I have in fact extrapolated with my pocket calculator to the year 2039: at that point there will be more students of metaphor than people (cited in Punter, 2007, p. 7).

In essence, Booth's jesting, though revealing, evaluation includes recognition of the pervasiveness of metaphor in scholarship in the twentieth century and beyond. Since 1978, scholarship on metaphor has not abated, according to David Punter (2007, p. 7). Writing about the subject has engaged scholars and philosophers uninterruptedly since Aristotle (Romano, 2011).

However, Punter (2007) points out that scholarship on metaphor has drastically changed since Booth's predictions due to various reasons. Among these reasons is the introduction of new theories of literature, the new approaches to the text in the writings of thinkers like Jacques Lacan and Jacque Derrida, the rise of cultural criticism, and the attention paid to the formative power of tropes and rhetoric (2007, p. 7). Furthermore, Punter (2007) holds that metaphor is so integral to the language of communication without which language would look "drab and extremely restricted" (p. 3). He explains that language is a continuous process of translation, translating things we find difficult to apprehend into things we can easily "apprehend, or conceptualize, or visualize" (p. 3).

Carlin Romano (2011) asserts that understanding the concept of metaphor has so far been approached differently from the perspectives of three major theories: Substitution Theory, Comparison Theory, and Interaction Theory. The substitution view looks at $\mathrm{B}$ as a replacement of $\mathrm{A}$ in $\mathrm{A}$ is $\mathrm{B}$. The comparison approach views $\mathrm{A}$ as similar to B in some features. However, in the third theory, A and B combine in a certain way to yield a novel metaphorical meaning. Besides, Romano (2011) points out that, in the twentieth century, metaphor was an attractive topic across various disciplines, including philosophy, psychology, cognitive sciences along with linguistics and literature. He concludes that metaphor has become "the crux of all thought, and maybe all human understanding" (par. 6).

Eva Feder Kittay (2009) studies metaphor and revisits the Semantic Theory of Metaphor. Her book provides an analysis of the cognitive impact of metaphor. For Kittay, metaphor transfers meaning, not between two terms, but between two semantic fields, and provide connections that bind the literal use of terms. Kittay attempts to find the connection between the metaphoric and literal significance of terms.

Metaphor has always pervaded the writings of philosophers and the studies of linguists and literary critics from the Greeks till today. Some philosophers have advocated the important impact of metaphors on rhetoric, cognition, and thought. However, opponents of metaphor disdained its embellishment of language (Kittay, 1987) The earliest opponent of metaphor is Plato who detested it as finery of rhetoric. To the contrary, Aristotle, the prominent advocate of the significance of metaphor in language and rhetoric, points out the vital role of metaphor in giving language clarity, vividness, and sweetness. In his treatise on Rhetoric, he defines metaphor as "the movement [epiphora] of an alien [allotrios] word from genus to species or from species or genus or from species to species or by analogy" (Rhetoric, 7, 1457b). This definition highlights a major principle that metaphors are based on analogy (resemblance) between two objects. He further points out that metaphor is composed of words that have significance and thus create knowledge ("words signify something, so ... create knowledge" [Rhetoric, 1410b]). Besides, he holds that forming metaphors does not come from learning, but rather requires a special talent (Rhetoric, $8,1405 \mathrm{a}$ ). 
John Kirby (1997) emphasizes the massive impact of Aristotle on Western culture in the fields of rhetoric and poetry and argues that the terminology and ideas of Aristotle have influenced the debate over metaphor for many centuries. Even when modern scholars suggest different criteria for studying metaphor, they do that against "the grain of the Aristotelian tradition" (Kirby, 1997, p. 518). Similarly, Wood (2015) asserts that Aristotelian views have dominated Western thought and have been always present in the minds of theorists on metaphor for more than 23 centuries (p. 161).

Kovecses (2002), a prominent proponent of CMT, sums up the major characteristics of the traditional, mainly Aristotelian, perception of metaphor in the following points: first, metaphor is a feature of language and thus belongs to the linguistic domain; second, it is a rhetorical and an artistic device; third, it compares two metaphysical and physical objects that have some resemblance to understand the metaphysical through our experience of the physical; fourth, metaphor requires a special talent to produce it; and finally, metaphor is not essential to language and can be disregarded (pp. vii-viii). These features are mainly Kovecses' understanding of the Aristotelian perception of metaphor as expressed in the Poetics and Rhetoric. The first 4 features inferred by Kovecses from the traditional perception of metaphor are directly derived from Aristotle and his influence on centuries of scholarship on the subject. Kovecses' perception of Aristotle is, in fact, an elaboration on Johnson's view that Aristotle was the ancestor of the permeating assumptions that "skewed" Western understanding of metaphor for over two millennia (Wood, 2015, p. 161).

Lakoff and Johnson's (1980) CMT challenges the conventional Aristotelian concept of metaphor. Kovecses points out the major features of CMT in the following points: First, metaphor belongs to the domain of concepts and not of words. Second, metaphor is not merely an artistic and a rhetorical device, but is a means of understanding concepts. Third, metaphor is not based on analogies. Fourth, the production of metaphor does not require a special talent as Aristotle prescribes. And fifth, metaphor is not meant for ornamentation in language, but is essential for human cognition (pp. vii-viii). As clear from these points, Lakoff and Johnson underscore their departure from Aristotle. These features indicate a re-evaluation of and revolution against the traditional views inherited from Aristotle (Wood, 2015, p. 180). Wood points out that Lakoff and Johnson trust that they have brought philosophical speculation of 2300 years to an end, and believe that "philosophy can never be the same again" after their study (2015, p. 362).

CMT divides conceptual metaphor into six sub-categories: structural, ontological, and orientational metaphors along with personification, metonymy, and synecdoche. CMT grounds an understanding of conceptual metaphors in their correspondence with experience. Connecting experience to metaphor is an essential stipulation for the cognitive processing of concepts. Lakoff and Johnson (1980) argue that "we conceptualize the nonphysical in terms of the physical - we conceptualize the less clearly delineated in terms of the more clearly delineated" (p. 59). Orientational metaphors, for instance, "derive from the fact that human organism responds to its lotus within a given physical environment" (Nuessel, 1982, p. 188). Therefore, the erect human body in the case of happiness enhances the metaphor HAPPY IS UP, and the plummeting body in case of sadness justifies the metaphor SAD IS DOWN.

Coherence is another feature of conceptual metaphors. In ARGUMENT IS WAR, the metaphor is to indicate the shared properties of the two concepts A and B. They share overlapping entailments that help structure the metaphor and form our conception of the target concept or domain in terms of the source concept or domain. The invoked entailments give coherence to the metaphor. Lakoff and Johnson (1980) argue that "human thought processes are largely metaphorical" (p. 6).

Lakoff and Johnson's influential theory has ignited an interest in the interdisciplinary epistemic connection between cognitive science and literary studies (Geert Brône \& Jeroen Vandaele, 2009, p. 10). Similarly, Van Oort (2003) holds that since Lakoff and Johnson's Metaphors We Live By, cognitive poetics has provided "a systematic theory of the mind in which literature is not merely peripheral but central to the understanding of human psychology" (cited in Brône \& Vandaele, 2009, p. 10). Drawing on Lakoff and Johnson's study of conceptual metaphors in the everyday language of communication, this study approaches the conceptual metaphors of time utilizing the methodology of the infrequently trodden new cognitive poetics. Gavins and Steen (2003) explain cognitive poetics as follows:

[Cognitive poetics] suggests that readings may be explained with reference to general human principles of linguistic and cognitive processing, which ties the study of literature in with linguistics, psychology, and cognitive science in general. Indeed, one of the most exciting results of the rise of cognitive poetics is an increased awareness in the social sciences of the special and specific nature of literature as a form of cognition and communication. What is noted at the same time, however, is that this special position of 
literature is grounded in some of the most fundamental and general structures and processes of human cognition and experience, enabling us to interact in these special and artistic ways in the first place (cited in Louwerse \& Van Peer, p. 432).

Reuven Tsur's term "cognitive poetics" is, in essence, a critical approach to literary criticism which encourages a dialogue between the studies of literature using the tools of cognitive linguistics, which is originally a branch of cognitive science (Brône \& Vandaele, 2009, p. 13). This is similar to Margaret Freeman's (2007) proposition of studying literature using the insights of cognitive linguistics. Cognitive poetics or cognitive stylistics has witnessed noticeable developments in the last few decades through "research in an area at the interface between linguistics, literary studies, and cognitive science” (Semino, 2009, p. 64; Semino \& Culpeper, 2002; Tsur, 1992, 2003). In the last decades, scholars like Louwerse and Van Peer (2009), Tony E Jackson $(2002,2005)$ have contributed numerous studies on using the concepts of cognitive linguistics in producing empirical studies of literature. These scholars include, among others.

Some critics are skeptical of the use of cognitive poetics in interpreting literature. Raymond Tallis, for instance, dismisses what he calls the new phenomenon of 'neuromania' or 'Darwinitis' (p. ix, cited in Anderson, paragraph 3). Contrary to Tallis, Amy Cook (2010), in his book, Shakespearean Neuroplay: Reinvigorating the Study of Dramatic Texts and Performance through Cognitive Science advocates the use of cognitive linguistic concepts. Cook draws on Giles Fauconnier's Conceptual Blending Theory and Lakoff and Johnson's Conceptual Metaphors. Cook advocates the utilization of interdisciplinary approach and underplays the strict disciplinary studies and describes 'disciplinary walls' as 'figments of the imagination' (p. ix, cited in Anderson, paragraph 3). Cook believes that interdisciplinary approaches provide a significant method to explicate and add to disciplinary norms (p. ix, cited in Anderson, paragraph 3).

In light of the foregoing discussion, this study finds in CMT a helpful tool to understand the abstract and elusive concept of time in the sonnets of Shakespeare. In some of his sonnets, Shakespeare provides a cluster of different types of conceptual metaphors that shed light on the multidimensionality of time and the manifestations of its effects on human experience. These metaphors are linked to the human experience and thus guide our understanding of the compelling concept of time.

\section{Discussion}

The use of CMT in this section is meant to develop our understanding of the concept of time via source domains that have an experiential dimension. These sub-headings give the reader a variety of perspectives that have experiential scope from which to examine time and understand its abstraction and evasiveness. The conceptual categories addressed in this section address the creative metaphorical productivity of Shakespeare and they fall under the umbrella of newly trodden conceptual approach of cognitive poetics. The section uses the cognitive-linguistic method to uncover the literary achievement of Shakespeare in language use which transcends the linguistic aptitude of normal individuals and even communities.

\subsection{Structural Metaphors}

For Lakoff and Johnson (1980) structural metaphors are those metaphors in which "one concept is metaphorically structured in terms of another" (p. 14), as in ARGUMENT IS WAR. This metaphor is extracted from metaphorical linguistic expressions in such sentences as:

Your claims are indefensible.

He attacked every weak point in my argument.

His criticisms were right on target.

I demolished his argument.

I've never won an argument with him. (Lakoff \& Johnson, 1980, p. 9)

From around 50 sonnets that address the topic of time, we can extract a group of structural metaphors in which time, in all these cases, is the target domain onto which constituents from a variety of source domains are mapped. The purpose of this process is to provide understanding of the target domain of time. Following is a number of such metaphors:

\section{TIME IS WAR}

Time is also understood in terms of human experience with a hostile enemy. In sonnet 2, for example, it is described as a besieger that lays a siege to the young friend's face, draw wrinkles there, and sink his eyes deeper into their sockets. The poet suggests a solution to the young man, namely to have a child that can renew the 
beauty of the youth's adorable face. In the first quatrain, the poet describes time's assault on the beautiful youth, as thus:

When forty winters shall besiege thy brow,

And dig deep trenches in thy beauty's field,

Thy youth's proud livery, so gazed on now,

Will be a tattered weed of small worth held ... (Italics added).

The metaphoric expressions in italics are evidence of the conceptual metaphor. The following figure shows how the constituents of the source domain of WAR correspond with the constituents of the target domain of TIME. As in CMT, the mapping is unidirectional from the source domain to the target domain, but not the other way round.

$\begin{array}{ll}\text { Source: War } & \text { Target: TIME } \\ \text { Besiege } & \Rightarrow \text { time leads to change }\end{array}$

Dig deep trenches in beauty's field $\Rightarrow$ age draws wrinkles on the face of the youth

Proud livery $\quad \Rightarrow$ the body of the youth

Tattered weed $\quad \Rightarrow$ future aging body of the youth

The metaphorical linguistic expressions of the source domain with their experiential dimension enable us to understand the equivocal abstract target concept of time. Kovecses (2010) argues that "it is the metaphorical linguistic expressions that reveal the existence of the conceptual metaphors" (p. 28). He further explains that "The terminology of a source domain that is used in the metaphorical process is one kind of evidence for the existence of conceptual metaphor" (p. 28). In light of the foregoing discussion, Shakespeare's creativity converges with CMT premises.

Moreover, there is a metonymy in using "winters" to stand for years or PART FOR THE WHOLE in line 1 of the sonnet. Traditionally, this sort of metonymy is called synecdoche and is included as one of the categories of conceptual metaphors in Lakoff and Johnson (1980, p. 54). And winters in this sonnet structure another sub-metaphor: WINTERS ARE SOLDIERS. They dig trenches on the battlefield to strengthen their siege of the young man. The defence suggested by the poet is to have a child to retain the young man's beauty ("Proving his [the child's] beauty by succession thine ..." (sonnet 2,12 ).

\section{TIME IS AN INVINCIBLE FORCE}

In this metaphor, the poet structures the target domain of time in terms of the source domain of an invincible force. To show the impossibility of defeating time, the sonnet 65 gives examples of so powerful objects that are crushed by time. In quatrain one, he mentions samples of objects that are controlled by time's invincible raging force, namely brass, stone, the earth, and the vast sea:

Since brass, nor stone, nor earth, nor boundless sea

But sad mortality o'er-sways their power,

How with this rage shall beauty hold a plea,

Whose action is no stronger than a flower? (Italics added)

In the second quatrain, the poet gives further examples of strong phenomena that are crushed by the battering siege of time. It ruins unassailable rocks and gates of steel. The poet concludes that nothing can stop time's strong hand from spoiling anything:

O, how shall summer's honey breath hold out

Against the wrackful siege of batt'ring days,

When rocks impregnable are not so stout,

Nor gates of steel so strong, but time decays? (Italics added)

The target domain, TIME, is structured in terms of the structure of the source domain, INVINCIBLE FORCE. The constituents of the source domain are mapped onto those of the target domain. The following figure demonstrates the correspondence between the constituents of the source domain and those of the target domain in the first two quatrains of sonnet 65 :

Source: INVINCIBLE FORCE Target: TIME

$o$ 'er-sways their power $\Rightarrow \quad$ overpowers everything 


$\begin{array}{lll}\text { rage } & \Rightarrow & \text { ruthlessness } \\ \text { wrackful siege } & \Rightarrow & \text { destructive force } \\ \text { batt'ring days } & \Rightarrow & \text { erodes rocks and gates of steel } \\ \text { stout enemy } & \Rightarrow & \text { overpowers brass, rocks, earth, boundless sea, and gates of steel } \\ \text { time decays } & \Rightarrow & \text { wears out everything, strong or weak }\end{array}$

If time does all this damage to all the elements of nature, then the poet wonders how can the beauty of the young man, which has no more strength than that of a fragile flower, stand against the assaults of the invincible force of time? The metaphor is meant to create awareness in the mind of the young friend of the poet about the destructive nature of time that will eventually devastate his beauty. However, the poet consoles the young friend that his verse will defy time and give immortality to the young friend ("O none, unless this miracle have might: / That in black ink my love may still shine bright (sonnet 65, 13-14).

\section{TIME IS CHANGE}

In this metaphor, the target concept of TIME is conceptualized in terms of the source domain concept of CHANGE. Restless time entails many changes in natural phenomena. These entailments resulting from the irreversible movement of time denote change and mutability. The entailments in this sonnet are related to time's guiding summer (youth) to repugnant winter (old age), as clear in the second quatrain of sonnet 5:

For never-resting time leads summer on

To hideous winter, and confounds him there,

Sap checked with frost and lusty leaves quite gone,

Beauty o'er-snowed and bareness everywhere ... (italics added)

Time keeps moving and inflicting change on everything. In the first quatrain of sonnet 5 , we are told of the change rendered on human beings, whose lives move in life cycles. Time leads humans up to youth and maturity, and the same way it leads them down to old age and death. The metaphoric expressions in italics convey the meaning of change and provide evidence of the metaphor TIME IS CHANGE:

Those hours that with gentle work did frame

The lovely gaze where every eye doth dwell

Will play the tyrants to the very same,

And that unfair which fairly doth excel. (italics added)

The poet recognizes the impossibility of stopping the passage of time. However, to stop the destructive nature of time, he suggests that the young man can distill his essence through a child that will maintain that essence even at old age. In the couplet, the poet puts this idea forward through the metaphor, HUMAN BEINGS ARE FLOWERS:

But flowers distilled, though they with winter meet,

Leese but their show; their substance still lives sweet. (Sonnet 5, 13-14, italics added)

The sonnet also includes the two conceptual metaphors of YOUTH IS SUMMER and OLD AGE IS WINTER. These metaphors recur throughout Shakespeare's sonnets that address the theme of time. Whenever Shakespeare refers to the experience of old age and death, he conceptualizes that in terms of our experience of winter, the season that indicates the death of nature. He does the same with the other seasons. Each stage of life is conceptualized in terms of one of the seasons: youth and maturity in terms of summer, old age and death in terms of winter. In sonnet 5, for instance, he advises his beautiful young friend not to allow time to abolish his glamor by allowing the "never-resting time" to lead his "summer on/To hideous winter" (5-6). Similarly, the poet warns the young friend not to allow time to destroy his beauty of youth: "Then let not winter's ragged hand deface/In thee thy summer" (sonnet 6,1-2).

Similarly, in sonnet 73 , he tackles the theme of old age and all the changes that the poet has suffered from youth to old age and death. In quatrain 1, the poet talks about his personal fall season which will lead to the winter season. As common in Shakespeare, the effects of time on human life are conveyed through analogies with plants, thus highlighting the overall destructive nature of time on everything. It is the season of yellow leaves, few leaves, or no leaves when the boughs shake in cold temperature:

That time of year thou mayst in me behold,

When yellow leaves, or none, or few, do hang 
Upon those boughs which shake against the cold,

Bare ruined choirs where late the sweet birds sang. (1-4, italics added)

In the second quatrain, time will guide this season into that of winter, the season of death.

In me thou seest the twilight of such day

As after sunset fadeth in the west,

Which by and by black night doth take away,

Death's second self, that seals up all in rest. (Italics added)

In the third quatrain, the poet describes his situation at this stage of life:

In me thou see'st the glowing of such fire

That on the ashes of his youth doth lie,

As the death-bed whereon it must expire,

Consum' $d$ with that which it was nourish'd by. (Italics added)

To explain his situation at old age, the poet builds another conceptual metaphor, LIFE IS FIRE, in which he maps constituents of the source domain of FIRE onto those of the target domain of LIFE: glowing fire corresponds with youth, the glimpse of fire under the ashes with old age, and expiration and total consumption into ashes with death. This converges with Shakespeare's consistent metaphor of OLD AGE IS WINTER.

\subsection{Ontological Metaphors}

Ontological metaphors enable us to understand "our experiences in terms of objects or substances," as they allow us "to pick out parts of our experiences and treat them as discrete entities or substances of a uniform kind" (Lakoff \& Johnson, 1980, p. 25). An example of these metaphors is INFLATION IS AN ENTITY. Lakoff and Johnson (1980) argue that this metaphor is extracted from such sentences as:

Inflation is lowering our standard of living.

If there's much more inflation, we'll never survive.

We need to combat inflation.

Inflation makes me sick (p. 26).

\subsubsection{Ontological Metaphors Through Personification}

Personification is probably the most obvious form of ontological metaphor in Shakespeare's sonnets, according to Lakoff and Johnson (1980). They argue that in this type of metaphor, "the physical object is further specified as being a person." They explain that "[t]his allows us to comprehend a wide variety of experiences with nonhuman entities in terms of human motivations, characteristics, and activities" (p. 28).

We can recognize three interrelated metaphors of this type in the sonnets of Shakespeare: TIME IS AN ENEMY, TIME IS AN ADVERSARY, and TIME IS A BESIEGER. These metaphors overlap with the structural metaphor TIME IS WAR. In sonnets 2 and 65, the invincible time is conceptualized as a besieging army that surrounds and conquers human beings, the young man being a sample that represents all humanity. Shakespeare, in sonnet 2, uses winter as a synecdoche for a year, and years as a metonymy for time. In the first quatrain, the army of the years besieges the face of the young friend and digs trenches in his face and eventually changes his elegant clothes into ragged ones. The quatrain reads as thus:

When forty winters shall besiege thy brow

And dig deep trenches in thy beauty's field,

Thy youth's proud livery, so gazed on now,

Will be a tattered weed, of small worth held. (Italics added)

"[Y]outh's proud livery" is a metonymy for the handsome body of the young man. The expression "tattered weed" is a metonymy for the aging body of the young man. The young striding man will ultimately deteriorate into an old man whose warm blood will become cold. The poet's solution to this universal problem is to have children that will renew the young man's juvenility and prevent time from destroying him ("This were to be new made when thou art old,/And see thy blood warm when thou feel'st it cold," sonnet 2, 13-14).

Similarly, in sonnet 65 , the young man is besieged by the army of "battering days" (sonnet 65,6 ). In the second 
quatrain,

O how shall summer's honey breath hold out

Against the wrackful siege of batt'ring days,

When rocks impregnable are not so stout,

Nor gates of steel so strong but time decays? (Italics added)

The metaphor reiterates that of sonnet 2, but the creativity of Shakespeare endows an innovative input upon the source domain to endow the metaphor with novelty, vividness, and fresh energy.

\section{TIME IS A TYRANT}

This is also a metaphor in which the target domain of TIME is specified by the source domain of TYRANT. This way, we can understand the "nonhuman entity" of time "in terms of human motivations, characteristics, and activities" (Lakoff \& Johnson, 1980, p. 28). For instance, in sonnet 16, time is presented as a bloody tyrant. The poet wonders why the young man does not wage war against that enemy:

But wherefore do not you a mightier way

Make war upon this bloody tyrant, time... (1-2, italics added)

The ontological metaphor about TIME here is formed with the source domain of BLOODY TYRANT. Personalizing time as thus, the poet indicates that there should be a response to it by the young man. He proposes that the young friend should look for a better defence against the tyranny of time than the poet's "barren rhyme," suggesting marriage and children as an outlet. The poet argues that neither his "inward worth" nor "outward fair" will give him the permanence he longs for. He recommends that his friend ought to understand the paradox that to maintain himself, he should give himself to a child ("To give away yourself keeps yourself still, /And you must live, drawn by your own sweet," (Sonnet 16, 13-14).

The metaphor TIME IS A TYRANT recurs in sonnet 115 as Shakespeare refers to time's tyranny in line 9. In the second quatrain of the sonnet, he gives examples of tyrant time's heinous crimes:

But reckoning time, whose millioned accidents

Creep in 'twixt vows, and change decrees of kings,

Tan sacred beauty, blunt the sharp'st intents,

Divert strong minds to th' course of alt'ring things... (Italics added)

These examples of the tyrannous acts of time echo the examples given in sonnet 19. Of what the tyrant time can do, the poet says that time creeps between lovers' vows of love, alter kings' orders, darken the ideal beauty of a lover, dull the strong intentions of lovers, and convert the determined minds to succumb to circumstances (5-9). The metaphor makes it possible to understand time through the behavior of the personalized source domain TYRANT.

\section{TIME IS A SPEEDY RUNNER}

This is another ontological metaphor of time through the personalized source domain SPEEDY RUNNER. Shakespeare develops this metaphor in sonnets 19 and 65. The sonnets mark the high pace of the movement of time. In sonnet 19, for example, he refers to time as "swift-footed" (line 6) in a poem in which he conceptualizes time as a ferocious beast that destroys everything. Likewise, in sonnet 65 , he refers to the "swift foot" of time in line 11. The writer structures the metaphor in terms of a quick-paced runner who gives no chance for human beings, non-human beings, and natural phenomena to defy his invincible force. In the two cases, the poet offers his verse as the only defence against time's eminent destruction of his friend.

\section{TIME IS A SLUT}

In sonnet 55, Shakespeare forms a conceptual metaphor in which he bases the target domain TIME in terms of the personalized source domain SLUT. The human experience of a slut indicates a dirty woman shifting loyalty with no ethics of constancy. This is built in the phrase sluttish time in line 4. In the first quatrain, which includes this phrase, time is shown to be a destructive slut, turning against one monument after another without faithfulness to anything. It turns against marble and gilded monuments of princes. These statues are either wasted in war, or fire, or under the fluctuations of the weather. This sluttish nature of time entails the reaction of the poet, who offers poetry as the only means to immortalize his young friend till the Day of Doom against the destructiveness of capricious time. In quatrain one, the poet lays the comparison between the young friend immortalized in his poetry and princes formulated in sculpture that are subjected by fickle time: 
Not marble nor the gilded monuments

Of princes shall outlive this pow'rful rhyme,

But you shall shine more bright in these conténts

Than unswept stone, besmeared with sluttish time. (1-4, italics added)

In the couplet, the poet confirms that poetry which is not ruled by time, will outlive those forms of art which are subject to the dereliction of the unfaithful slut, time:

So till the judgment that yourself arise,

You live in this, and dwell in lovers' eyes. (13-14, italics added)

These two lines echo St. Augustine's theory of time, which distinguishes human time from eternal time. The Young man will live in Shakespeare's poetry during human time till the Day of Judgment when he will rise from his tomb and live eternally.

\subsubsection{Ontological Metaphors Through Objects}

\section{TIME IS A MONSTER}

This is another ontological metaphor in which Shakespeare presents time as a monster that destroys everything around it, including the most ferocious animals. He recruits several examples to define the destructive and ruthless brutality of that monster. He illustrates the "heinous crime[s]" of time as thus:

Devouring Time, blunt thou the lion's paws,

And make the earth devour her own sweet brood;

Pluck the keen teeth from the fierce tiger's jaws,

And burn the long-lived phoenix in her blood;

Make glad and sorry seasons as thou fleetest. (Sonnet 19, 1-5, italics added)

Even fierce animals cannot escape the destruction of this monster. Naturally, the young friend of the poet is no exception. According to CMT, we define our reality in terms of metaphor and then act according to the metaphor. Therefore, a new reality is defined by the metaphor. This new reality dictates a necessity for taking action to challenge the ruthlessness of the monstrous time. The action taken is the poet's verse that will preserve the youth of his friend despite the monstrosity of time. He challenges the criminal monster to dare draw wrinkles on the face of the youth and make him look old:

But I forbid thee one most heinous crime:

Carve not with thy hours my love's fair brow,

Nor draw no lines there with thine ántique pen.

Him in thy course untainted do allow

For beauty's pattern to succeeding men. (Sonnet 19, 8-12)

In the couplet, he confirms that despite time and his crimes, the poet's verse will keep his friend ever young:

Yet do thy worst, old Time; despite thy wrong,

My love shall in my verse ever live young. (Sonnet 19, 13-14).

This conceptual metaphor joins the rest of the ontological metaphors in drawing the monstrosity of time and its destructive nature.

\subsubsection{Ontological Metaphors Through Metonymy}

Metonymy is defined by Lakoff and Johnson (1980) as "... using one entity to refer to another that is related to it (p. 35). They give the following example: "we need some good heads on the project." They explain that "good heads" in this sentence means "intelligent people" (p. 30). They also contend that synecdoche is a sub-case of metonymy. It simply means "the part stands for the whole" (p. 36).

In CMT, metonymy differs from metaphor in processing conceptualization. Whereas metaphor is a process of construing one concept in terms of another, metonymy provides understanding by allowing us to use "one entity to stand for another." The function of metonymy is referential along with its function of creating understanding (Lakoff \& Johnson, 1980, p. 54). Shakespeare develops several such conceptual forms, most notable is TIME IS A SCYTHE. 


\section{TIME IS A SCYTHE}

In this case, the scythe is a metonymy for a reaper. It is what Lakoff and Johnson (1980) call an OBJECT FOR USER metonymy (p. 31). This structure enables us to conceptualize an object in terms of its relation to something or somebody else (Lakoff \& Johnson, 1980, p. 31). The use of metonymy here stems from the main focus of the experience the poet wants to bring to the fore, namely the act of cutting all beings and things. If the focus was on the reaper as in TIME IS A REAPER, the main point will not be the experience of the destructive act of ruthless cutting of all beings, but the constructive act of collecting the harvest. After all, Shakespeare's aim is to express his pessimistic view of the human experience of time. Moreover, this metonymy is grounded in western culture as it gives immediacy to the 14th-century image of Black Death as a Grim Reaper with his iconic crooked scythe during the time of the plague in Europe which harvested millions of people (Dellinger, 2004).

Shakespeare conceptualizes time in terms of the scythe that resects everything in sonnets 12,60,100, and 126. For example, in sonnet 12, time keeps moving consistently and irreversibly, leading everything to downfall and death. The perception of time presented in the metaphor creates a new reality that entails action to encounter it. Accordingly, the poet urges his young friend to get married and have children. Having children is one of three solutions the sonnets suggest to defy the damage caused by time. In the couplet of sonnet 12 , the poet puts that suggestion very clearly:

And nothing 'gainst Time's scythe can make defense

Save breed to brave him when he takes thee hence. (Italics added)

Similarly, in sonnet 60 , the metaphor recurs in line 12 , and poetry is offered as a solution to encounter time and immortalize the young friend:

And nothing stands but for his scythe to mow

And yet to times in hope my verse shall stand,

Praising thy worth, despite his cruel hand. (12-14, italics added)

Likewise, the metaphor is reiterated in sonnet 100, again offering poetry as the solution to the problem of time. The poet invokes the Muse to

Rise, resty Muse: my love's sweet face survey,

If time have any wrinkle graven there;

If any, be a satire to decay,

And make time's spoils despised everywhere:

Give my love fame faster than time wastes life,

So thou prevent'st his scythe and crooked knife. (9-14, italics added)

The metonymy OBJECT FOR USER in the SCYTHE FOR REAPER is used in this sonnet to convey the same meaning of destruction highlighted in the other sonnets. The invocation to the Muse serves in inspiring the poet to generate verse that can thwart the destructive acts of time, such as engraving wrinkles on his face, sending him to decay, listing him among its spoils, wasting his life, or finally reaping him with its scythe.

The metonymy recurs once more in sonnet 126 . Here, the poet complains of the waning love of his friend, explaining that, in the end, he will be reaped with time's sickle after the grains of sand in the sandglass are over:

$\mathrm{O}$ thou, my lovely boy, who in thy power

Dost hold time's fickle glass, his sickle hour, (1-2, italics mine)

In this sonnet, Shakespeare mentions the sandglass that the Grim Reaper would hold and wait till the last sands pour down into the lower container, and then reap the victim with the sickle (Dellinger, 2004).

4.2.4 Ontological Metaphors Through Synecdoche

\section{TIME IS WAVES}

Sonnet 60 is the only one in the sequence of Shakespeare's sonnets that builds the metaphor of MINUTES as WAVES. Minutes are presented as a synecdoche for time. By using the synecdoche of minutes, the poet wants to emphasize the passage of time in which every small division carries change and brings human beings closer to the death which is their final anchor. This concept converges with St. Augustine's view of the passage of time. The sonnet addresses the issue of the persistent irreversible passage of time (Confessions; Book 11, chap. 14). 
In the first two quatrains:

Like as the waves make towards the pebbl'd shore,

So do our minutes hasten to their end;

Each changing place with that which goes before,

In sequent toil all forwards do contend.

Nativity, once in the main of light,

Crawls to maturity, wherewith being crown'd,

Crooked eclipses 'gainst his glory fight,

And Time that gave doth now his gift confound. (1-8)

In these lines, there is mapping of the constituents of the source domain WAVES onto the constituents of the target domain TIME. The following figure shows that correspondence:

Source: WAVES

waves

pebbl'd shore

waves rush to the shore

birth of wave

\section{Target: TIME}

$\Rightarrow$ minutes

$\Rightarrow \quad$ death

$\Rightarrow \quad$ minutes hasten to the end of life

$\Rightarrow \quad$ Nativity

Crooked eclipses 'gainst his glory fight $\Rightarrow \quad$ time inflicts change on the mature man

Splash of the wave at the shore $\Rightarrow$ Time ... his gift confound

There is correspondence between the racing of the waves toward the shore and a human life cycle. Accordingly, waves, which are a synecdoche for time, race in a cluster like the minutes of human life. Also, individual waves have a life cycle like that of human beings. Its initial formation is like the birth of a human being, the wave gathering strength is like the growth of a person to maturity, splashing against the shore and retreating is analogous to a human being exhausting his budget of minutes and dying. Besides, using minutes indicates the Elizabethan interest in the division of time into minutes and hours due to the progress in clock-making in Shakespeare's age (Moreira, 2017). This metaphor is in line with Aristotle's definition of time as divisible and countable. It is related to movement and change and is marked by them. It has the components of past, present, and future. Accordingly, a wave that has splashed against the shore goes to the domain of the past, the one ready to splash is the present, and the waves in line, heading to the shore, represent moments of the future. Our experience of time is understood, here, in terms of our experience of the waves.

\subsection{Orientational Metaphors}

Theoretically, orientational metaphors are organized in terms of "a whole system of concepts with respect to one another" (Lakoff \& Johnson, 1980, p. 14). They are grounded on the basis of spatial orientations which "provide an extraordinarily rich basis for understanding concepts in orientational terms" (Lakoff \& Johnson, 1980, p. 23). These metaphors take their name from their "spatial orientation: up-down, in-out, front-back, on-off, deep-shallow, central-peripheral" (Lakoff \& Johnson, 1980, p. 16). The writers argue that these spatial orientations stem from our movement in the surrounding environment. Therefore, there is a physical basis behind the construction of these metaphors. UP, for instance, reflects the upright physical stature at times of happiness, strength, and youth, whereas DOWN goes along with experiences in which we have a drooping stature, such as sadness, weakness, old age, sickness, and death. This spatial orientation becomes a concept in this type of metaphor (Lakoff \& Johnson, 1980, p. 16).

\section{TIME IS UP}

TIME IS UP provides a coherent system in which the spatial orientation is upward. In Shakespeare's sonnet 5, for instance, in lines 1-2 ("Those hours that with gentle work did frame/The lovely gaze where every eye doth dwell,") the poet talks about the generous gift of iconic beauty time endows upon the young man. People are allured with his beauty and they look up to him with admiration. Besides, the young man will be happy, confident, and thus will be feeling up and his spirits will rise. Sonnet 15, for example, shows how time takes humans up to perfection where they "[v]aunt in their youthful sap, at height decrease" (7). The words "vaunt" and "height" indicate an UP spatial orientation. In most of the sonnets about the young man, there is a presentation of the human life cycle. It starts with birth and ends in death, initially growing and rising to a peak 
and then declining and falling to old age. The spatial orientation of the initial stage is rising. This bright side justifies the construction of the TIME IS UP metaphor. Relevant to this metaphor, other interrelated metaphors can be constructed: SUMMER IS UP and YOUTH IS UP. These orientational metaphors are based on the fact that summer is a metonymy for youth.

However, sonnets addressed to the young friend urge him to heed the strokes of time on his charming beauty and offer three solutions to the menace of time, specifically, progeny, poetry, and love. Based on these solutions, we can infer four interconnected conceptual orientational metaphors, namely BEAUTY IS UP, PROGENY IS UP, VERSE IS UP, and LOVE IS UP.

\section{TIME IS DOWN}

This is the most pervasive and pessimistic metaphor in the sonnets, especially in those sonnets addressed to the young man. The set of concepts that organize the metaphor includes the need to maintain the fabulous beauty of the young man and, simultaneously, fear of old age and death. Time is an unavoidable menace to human life that leads humans and other beings to their eminent death as in sonnets $2,5,12,65,73$, and 100 . In sonnet 2 , for instance, the beautiful face of the young friend will be marred with wrinkles and his stout and beautiful stature will be wrecked and dilapidated in old age. Similarly, in sonnet 5, the poet advises the young man to distill his essence in a child before he reaches old age and be bereft of his beauty: "Beauty o'er-snowed and bareness everywhere: / Then were not summer's distillation left / ... Beauty's effect with beauty were bereft," (8-11). There is rarely a sonnet that tackles the issue of the young man that does not refer to old age and death. Along the same lines, sonnet 12 , recruits analogies from plants and natural phenomena that have a similar life cycle to that of humans, in which there is a rise to maturity and then descent to destruction and waste. In the process of decline, humans acquire a plummeting stature and finally fall dead. The poet forecasts what will happen to the young man: "Then of thy beauty do I question make, / That thou among the wastes of time must go" (Sonnet 12, 9-10). Likewise, in sonnet 65, the poet explains that all solid metals in nature cannot stand against the rage of time. The poet, in sonnet 73, explains the sad results of his sinking into old age and reaching the threshold of death.

Sonnet 100 is another example in which the poet points out the gradual damage his young friend will suffer under the strokes of time, till he is totally harvested and wasted by the scythe of time:

If Time have any wrinkle graven there;

If any, be a satire to decay,

And make Time's spoils despised everywhere.

Give my love fame faster than Time wastes life;

So thou prevent'st his scythe and crooked knife. (10-14, italics added)

In support of his orientational metaphors, Shakespeare enhances them with two relevant structural metaphors: YOUTH IS SUMMER and OLD AGE IS WINTER. Additionally, we can derive further orientational metaphors based on them: YOUTH IS UP, SUMMER IS UP, OLD AGE IS DOWN, and WINTER IS DOWN. In this context, we can understand the metaphorical force of SUMMER IS UP and WINTER IS DOWN in the following lines and many others like them in the sonnets:

For never-resting time leads summer on

To hideous winter, and confounds him there ... (Sonnet 5, 5-6)

The analogy between human life cycle and that of the plants is always available in Shakespeare's sonnets. Here is an example from sonnet 15 :

When I perceive that men as plants increase,

Cheered and cheque'd even by the self-same sky,

Vaunt in their youthful sap, at height decrease,

And wear their brave state out of memory... (5-8, italics added)

And another example of OLD AGE IS DOWN is extracted from sonnet 17:

So should my papers (yellowed with their age)

Be scorned, like old men of less truth than tongue ... (9-10)

The features attributed to old age, such as paleness, lack of energy, and absence of allurement are usually 
accompanied by plummeting, drooping, and sadness, which all indicate a downward stature of the human body. This combination of features and physical reaction produce the spatial orientational metaphor of OLD AGE IS DOWN. As time always ends the life cycle in death, two more orientational metaphors are developed in liaison with the foregoing metaphors, namely LIFE IS UP and DEATH IS DOWN.

Metaphors in this section overlap with the conceptual structural metaphor LIFE IS A JOURNEY. The journey starts at birth and ends in death. It is a life cycle in which time takes beings and natural phenomena from beginning to perfection and finally to death. Even natural phenomena, such as the sun, the day, the year have the same life cycle. These objects rise to a peak and then decline to an end. For instance, in sonnet 7, Shakespeare describes the journey of the sun from sunrise to midday to sunset and maps the various stages of that journey onto the human life cycle. At birth, the sun is celebrated as thus: "Lifts up his burning head, each under eye / Doth homage to his new-appearing sight (2-3, italics added). And having ascended to the dome of heaven, the sun is described as follows: "And having climbed the steep-up heavenly hill, / Resembling strong youth in his middle age" (5-6, italics added). Afterward, the sun starts descending to finally plunges into darkness: "But when from high most pitch, with weary car, / Like feeble age he reeleth from the day" (9-10, italics added). The comparison is rounded in the couplet: "So thou, thyself out-going in thy noon, / Unlooked on diest unless thou get a son" (13-14). The day, the violet, the leaves of lofty trees, the grass, and the young friend of the poet, all undergo the same life cycles as described in sonnet 12 . Eventually, all will be wasted by ruthless time. Similarly, time will lead summer to winter: "For never-resting time leads summer on / To hideous winter and confounds him there" (sonnet 5, 5-6). All will "fall to decay" and be wasted by ruthless time (sonnet 13, line 9). Furthermore, Shakespeare emphasizes that the stage of maturity or perfection in the human life cycle is short-lived, it is only "a little moment" (sonnet 15, line 2), and that our stay in that state of perfection is "inconstant" (sonnet 15, line 9).

\section{Conclusion}

This study has addressed the issue of time through the mediation of conceptual metaphors explained in Lakoff and Johnson's revolutionary book Metaphors We Live By and Kovecses' Metaphor: A Practical Introduction. Lakoff and Johnson's book provided a reasonable challenge for the deeply rooted conventional views of Aristotle about metaphor. Shakespeare's sonnets address the elusive concept of time through a cluster of conceptual metaphors in three major categories: structural, ontological, and orientational metaphors. Metonymy and synecdoche are also used as forms of conceptualization. Most important is the multiplicity of source domains Shakespeare recruits to explain the target domain of TIME. These source domains include (1) WAR, (2) INVINCIBLE FORCE, (3) ENEMY, (4) TYRANT, (5) MONSTER (6) SCYTHE (7) SPEEDY RUNNER, (8) WAVES, (9) CHANGE, (10) SLUT, (11) DOWN, and (12) UP (arrangement of these domains here is different from that in the discussion section). Domains 1-7 are terrifying, repulsive, destructive, hideous, brutal, ferocious, and cruel. When time is understood in terms of these frightening source domains, then we can realize the nature of the plight human beings have to suffer in this world. These scary media of understanding are not what philosophy addresses while trying to define the concept of time. Philosophers usually engage in discussions about the relationship of time and cognition, psychology, and the passage of time. The latter is reflected here in domain (8) of the waves. Source domain (9) reveals the feature of mutability and inconstancy of our fortune in this life which results from the flux of time. This impermanence of any state of Man breeds human uncertainty, doubt, and insecurity. This is confirmed by the sluttish and capricious nature of time in source domain 10, which puts the human mind to restlessness and incessant fright. The orientational domain DOWN (11) sums up all the foregoing source domains Shakespeare deploys to convey his pessimistic vision of time. The only positive source domain used in the sonnets is UP (12) that indicates some glimpse of hope in our experience of time. It is that orientational domain that marks human rising from childhood to maturity. Unfortunately, this positive experience of time is short-lived and ends in destruction and death.

Shakespeare's creativity expands the human consciousness of time and initiates more perspectives from which to evaluate human experience with that concept. These perspectives are based on the human experience of nature, society, and culture. The conceptual theory enables us to re-evaluate the creativity of Shakespeare and recognize the uniqueness of his approach to the concept of time. It shows how he goes beyond philosophers to show not only the procession of time, but also the disastrous effects of this phenomenon on our lives, consciousness, cognition, and outlook.

\section{References}

Al-Abdullah, M. (2020). Mental time travel in Shakespeare's sonnets: Aesthetic art in neuropsychological perspectives. English Language and Literature Studies, 10(1), 67-76. https://doi.org/10.5539/ells.v10n1p67

Anderson, M. (2013). Shakespeare and cognitive literary and performance studies. The Journal of Northern 
Renaissance,

5.

Retrieved

from

https://www.northernrenaissance.org/review-article-shakespeare-and-cognitive-literary-and-performance-st udies/Review

Aristotle. (1987). On Rhetoric: A Theory of Civic Discourse (George A. Kennedy Trans.). Oxford: Oxford University Press.

Aristotle. (2017). Poetics (Ingram Bywater Trans.). Digireads.com Publishing of Ottawa, Canada.

Brône, G., \& Vandaele, J. (Eds.). (2009). Cognitive poetics: Goals, gains and gaps. Berlin: Mouton de Gruyter. https://doi.org/10.1515/9783110213379

Burkley, M. (2017). Why metaphors are Important. Retrieved from http://www.psychologytoday.com/us/blog/the-social-thinker/201711/why-metaphors-are-important

Camp, E. (2006). Contextualism, metaphor, and what is said. Mind \& Language, 21(3), 280-309. https://doi.org/10.1111/j.1468-0017.2006.00279.x

Cohen, T. (1978). Metaphor and the Cultivation of Intimacy. Critical Inquiry, 5(1), 3-12. https://doi.org/10.1086/447969

Davidson, D. (1978). What metaphors mean. Critical Inquiry, 5(1), 31-47. https://doi.org/10.1086/447971

Dillinger, J. (2004). Terrorists and witches: popular ideas of evil in the early modern period. History of European Ideas, 30(2), 167-182. https://doi.org/10.1016/j.histeuroideas.2004.03.001

Freeman, M. (2007). Cognitive linguistic approach to literary studies: State of art in cognitive poetics. In G. Dirk \& C. Hubert (Eds.), The Oxford handbook of cognitive linguistics (pp. 1175-1202). Oxford and New York: Oxford University Press.

Gibbs, R. (1944). The poetics of mind: Figurative thought, language, and understanding. New York: Cambridge University Press.

Goodman, N. (1979). Metaphor as moonlighting. Critical Inquiry, 6(1), 125-130. https://doi.org/10.1086/448032

Hogan, P., \& Pandit, L. (Eds.). (2006). Cognitive Shakespeare: Criticism and theory in the age of neuroscience. Special issue of College Literature, 33(1).

Jackson, T. (2002). Issues and problems in the blending of cognitive science, evolutionary psychology, and literary study. Poetics Today, 23(1), 161-179. https://doi.org/10.1215/03335372-23-1-161

Jackson, T. (2005). Explanation, interpretation, and close reading: The progress of cognitive poetics. Poetics Today, 26(3), 519-533. https://doi.org/10.1215/03335372-26-3-519

Johnson, M. (1981). Introduction: Metaphor in the philosophical tradition. In M. Johnson (Ed.), Philosophical perspectives on metaphor (pp. 3-47). Minneapolis: University of Minnesota Press.

Kirby, J. (1997). Aristotle on Metaphor. The American Journal of Philology, 118(4), 517-554. https://doi.org/10.1353/ajp.1997.0056

Kittay, E. (1987). Metaphor: Its cognitive force and linguistic structure. Oxford: Oxford University Press.

Kovecses, Z. (2002). Metaphor: A practical introduction. Oxford: Oxford University Press.

Kovecses, Z. (2010). Metaphor: A practical introduction. Oxford: Oxford University Press.

Lakoff, G., \& Johnson, M. (1980). Metaphors we live by. Chicago: Chicago University Press.

Lakoff, G., \& Turner, M. (1989). More than cool reason. Chicago: The University of Chicago Press. https://doi.org/10.7208/chicago/9780226470986.001.0001

Louwerse, M., \& Van Peer, W. (2009). How cognitive is cognitive poetics? The interaction between symbolic and embodied cognition. In B. Geert \& V. Jeroen (Eds.), Cognitive poetics: Goals, gains and gaps (pp. 423-456). Berlin: Mouton de Gruyter.

Martinich, A. (1984). A theory for metaphor. Journal of Literary Semantics, 13(1), 35-56. https://doi.org/10.1515/jlse.1984.13.1.35

Nordquist, R. (2020). Understanding conceptual metaphors. Retrieved from https://www.thoughtco.com/what-is-conceptual-metaphor-1689899

Nuessel, F. (1982). Review of the book Metaphors We Live By, by George Lakoff and Mark Johnson. Lingua, 56, 185-200. https://doi.org/10.1016/0024-3841(82)90031-6 
Ortony, A. (1975). Why metaphors are necessary and not just nice. Educational Theory, 25, 45-53. https://doi.org/10.1111/j.1741-5446.1975.tb00666.x

Ortony, A. (1979). The role of similarity in similes and metaphors. In O. Andrew (Ed.), Metaphor and Thought (1st ed., pp. 186-201) Cambridge: Cambridge University Press.

Punter, D. (2007). Metaphor. London: Routledge. https://doi.org/10.4324/9780203965887

Pusey, E. (Tran.). (1999). The confessions of St. Augustine. Grand Rapids, MI: Christian Classics Ethereal Library.

Rassi, F. (2014). Time from Aristotle's perspective. World Scientific News, 6, 43-49.

Romano, C. (2011). What's a metaphor for? The Chronicle of Higher Education Review. Retrieved from https://www.chronicle.com/article/Whats-a-Metaphor-For-/128079

Semino, E. (2009). Text worlds. In B. Geert \& V. Jeroen (Eds.), Cognitive poetics: Goals, gains and gaps (pp. 33-71). Berlin: Mouton de Gruyter.

Semino, E., \& Culpeper, J. (Eds.). (2002). Cognitive stylistics: Language and cognition in text analysis. Amsterdam: John Benjamins. https://doi.org/10.1075/lal.1

Staughton, J. (2017). What is the grim reaper? Retrieved from https://www.scienceabc.com/social-science/what-is-the-grim-reaper-origin-story.html

Tsur, R. (1992). Towards a theory of cognitive poetics. Amsterdam: Elsevier.

Walton, K. (1993). Metaphor and prop-oriented make-believe. European Journal of Philosophy, 1(1), 39-57. https://doi.org/10.1111/j.1468-0378.1993.tb00023.x

Wood, M. (2015). Aristotle and the question of metaphor. Doctoral dissertation. Retrieved from file:///C:/Users/mu/Desktop/metaphors/Wood_Matthew_2015_thesis.pdf

\section{Copyrights}

Copyright for this article is retained by the author, with first publication rights granted to the journal.

This is an open-access article distributed under the terms and conditions of the Creative Commons Attribution license (http://creativecommons.org/licenses/by/4.0/). 